\title{
Improvement of Mathematics Learning Outcomes through Problem Based Learning in Class III
}

\section{Arif Rahman}

SDN Randurejo

aripomega@gmail.com

\section{Article History}

accepted 14/11/2020

approved 21/11/2020

published 26/11/2020

\begin{abstract}
The purpose of this study was to improve student learning outcomes in the Mathematical muple in grade III elementary schools with the Problem Based Learning (PBL) learning model. The research conducted was a Classroom Action Research (CAR) in two cycles, with each cycle consisting of two meetings. The stages of each cycle are planning, implementing, observing and reflecting. Each meeting is carried out a pre test and post test to determine the progress of students. In cycle I students who completed after carrying out the post test were $53 \%$. In cycle II participants students who complete after carrying out the post test are $90 \%$. These results indicate that the Problem Based Learning (PBL) learning model can improve the learning outcomes of students, especially Class III Mathematics at SDN 1 Randurejo.
\end{abstract}

Keywords: Problem based learning, mathematics, elementary school

\section{Abstrak}

Tujuan dari penelitian ini adalah untuk meningkatkan hasil belajar peserta didik pada mupel Matematiak di sekolah dasar kelas III dengan model pembelajaran Problem Based Learning (PBL). Penelitian yang dilakukan adalah Penelitian Tindakan Kelas (PTK) sebanyak dua siklus, dengan setiap siklusnya terdiri dari dua pertemuan. Tahapan setiap siklusnya adalah perencanaan, pelaksanaan, observasi dan refleksi. Setiap pertemuan dilakukan pre test dan post test untuk mengetahui perkembangan peserta didik. Pada siklus I peserta didik yang tuntas setelah melaksanakan post test sebesar 53\%. Pada siklus II peserta didik yang tuntas setelah melaksanakan post test sebesar $90 \%$. Hasil ini menunjukan bahwa model pembelajaran Problem Based Learning (PBL) dapat meningkatkan hasil belajar peserta didik khususnya mupel Matematika Kelas III di SDN 1 Randurejo.

Kata kunci: Problem based learning, matematika, sekolah dasar

Social, Humanities, and Education Studies (SHEs): Conference Series https://jurnal.uns.ac.id/shes 


\section{PENDAHULUAN}

Menurut Mujiono (1994:31) dalam proses belajar mengajar ada empat komponen penting yang berpengaruh bagi keberhasilan belajar siswa, yaitu bahan belajar, suasana belajar, media dan sumber belajar, serta guru sebagai subyek pembelajaran. Komponen-komponen tersebut sangat penting dalam proses belajar, sehingga melemahnya satu atau lebih komponen dapat menghambat tercapainya tujuan belajar yang optimal.

Penyempurnaan kurikulum adalah salah satu upaya peningkatan mutu pendidikan. Upaya itu berhasil jika ada perubahan pola kegiatan pembelajaran, dari yang berpusat pada guru kepada yang berpusat pada siswa, serta orientasi penilaian dari yang berorientasi diskriminasi siswa kepada yang berorientasi diferensiasi siswa. Keseluruhan perubahan itu akan menentukan hasil pendidikan. Ketepatan penilaian yang dilakukan sekolah, terutama yang berkaitan dengan penilaian kelas, memperlihatkan pencapaian hasil belajar siswa. Penilaian tersebut mempengaruhi pendekatan, kegiatan, dan sumber belajar yang diterapkan guru dalam proses pembelajaran.

Penilaian dan kegiatan pembelajaran bermuara pada penguasaan kompetensi yang diharapkan. Selama ini pelaksanaan penilaian di kelas

kurang mampu menggambarkan kemampuan siswa yang beragam karena cara dan alat yang digunakan kurang sesuai dan kurang bervariasi. Karena keterbatasan kemampuan dan waktu, penilaian cenderung dilakukan dengan menggunakan cara dan alat yang lebih menyederhanakan tuntutan perolehan siswa

Seperti di kelas III SDN 1 Randurejo, pada semseter 1 di ajarkan materi Selisih Bilangan Dalam Bentuk Soal Cerita. Namun, masih banyak siswa yang kurang paham terhadap materi tersebut. Hal tersebut dapat terlihat dari hasil belajar siswa yang terbilang rendah. Hal tersebut di sebabkan karena metode pembelajaran di kelas III B masih menggunakan metode konvensional.

Pembelajaran konvensional yang umum dilakukan adalah metode mengajar dalam bentuk ceramah atau informatif, dimana mengajar lebih banyak berbicara dalam menginformasikan fakta atau konsep. Sedangkan siswa hanya mendengarkan dan mencatat saja sehingga hal ini menyebabkan rendahnya minat belajar siswa yang berakibat siswa kurang dapat memahami peajaran yang disampaikan guru. Tentu saja hal tersebut dapat menyebabkan rendahnya hasil belajar siswa.

Salah satu usaha yang dapat dilakukan untuk meningkatkan hasil belajar siswa pada materi Selisih Bilangan Dalam Bentuk Soal Cerita adalah Melalui Model pembelajaran Problem Based Learning. Model pembelajaran Problem Based Learning adalah suatu cara mengajar di mana dalam pembelajaran tersebut dirancang masalah- masalah yang menuntut siswa mendapat pengetahuan yang penting, membuat mereka mahir dalam memecahkan masalah, dan memiliki strategi belajar sendiri serta memiliki kecakapan berpartisipasi dalam tim Model pembelajaran problem based learning (pembelajaran berbasis masalah), awalnya dirancang untuk program graduate bidang kesehatan oleh Barrows, Howard (1986) yang kemudian diadaptasi dalam bidang pendidikan oleh Gallagher (1995). Problem based learning disetting dalam bentuk pembelajaran yang diawali dengan sebuah masalah dengan menggunakan instruktur sebagai pelatihan metakognitif dan diakhiri dengan penyajian dan analisis kerja siswa.

Model pembelajaran problem based learning berlandaskan pada psikologi kognitif, sehingga fokus pengajaran tidak begitu banyak pada apa yang sedang dilakukan siswa, melainkan kepada apa yang sedang mereka pikirkan pada saat mereka melakukan kegiatan itu. Pada problem based learning peran guru lebih berperan sebagai pembimbing dan fasilitator sehingga siswa belajar berpikir dan memecahkan masalah mereka sendiri. Belajar berbasis masalah menemukan akar intelektualnya pada penelitian John Dewey (Ibrahim, 2000). Pedagogi Jhon Dewey 
menganjurkan guru untuk mendorong siswa terlibat dalam proyek atau tugas yang berorientasi masalah dan membentu mereka menyelidiki masalah-masalah tersebut. Pembelajaran yang berdayaguna atau berpusat pada masalah digerakkan oleh keinginan bawaan siswa untuk menyelidiki secara pribadi situasii yang bermakna merupakan hubungan problem based learningdengan psikologi Dewey. Selain Dewey, ahli psikologi Eropa Jean Piaget tokoh pengembang konsep konstruktivisme telah memberikan dukungannya. Pandangan konstruktivisme- kognitif yang didasari atas teori Piaget menyatakan bahwa siswa dalam segala usianya secara aktif terlibat dalam proses perolehan informasi dan membangun pengetahuannya sendiri (Ibrahim,2000).

Berdasarkan permasalahan yang dihadapi dan solusi yang ada, maka perlu dilakukan suatu tindakan berupa penerapan model pembelajaran Problem Based Learning untuk meningkatkan hasil belajar siswa pada materi Selisih Bilangan Dalam Bentuk Soal Cerita. Oleh karena itu peneliti tertarik untuk melakukan penelitian yang berjudul "Peningkatan Hasil Belajar Matematika Pada Materi Pengurangan Bilangan Dalam Bentuk Soal Cerita Melalui Problem Based Learning (PBL) Pada Siswa Kelas III SDN 1 Randurejo Kecamatan Pulokulon Kabupaten Grobogan Tahun Pelajaran 2020/2021"

\section{METODE}

Penelitian ini adalah penelitian tindakan kelas (Classroom Action Research) dengan menerapkan model pembelajaran Problem Based Learning (PjBL). Menurut Kurt Lewin dalam Kunandar (2011: 42) penelitian tindakan kelas ini terdiri dari empat tahapan dasar yaitu perencanaan (planning), pelaksanaan (acting), pengamatan (observing) dan refleksi (reflecting). Analisis penelitian ini adalah analisis deskriptif kuantitafif kualitatif dimana dalam penelitian ini selain penyajian hasil berupa data maupun angka peneliti juga menentukan bagaimana cara pengolahan hasil penelitian yakni dengan membuat analisisnya dengan menerapkan model penelitian Problem Based Learning (PBL). Penelitian ini dilaksanakan pada peserta didik kelas III SD Negeri 1 Randurejo Tahun Pelajaran 2020/2021 selama dua siklus secara daring menggunakan aplikasi Zoom dengan satu pertemuan disetiap siklusnya. Siklus I dilaksanakan pada tanggal 16 November 2020. Siklus II dilaksanakan pada tanggal 23 November 2020. Teknik pengumpulan data yang dilakukan dengan observasi dan tes baik pre test maupun post test. Observasi meliputi observasi keterlaksanaan model pembelajaran PBL, sikap peserta didik dan keterampilan. Untuk hasil belajar menggunakan tes melalui Google form

\section{HASIL DAN PEMBAHASAN}

Bagian ini sebanyak 800-1000 kata. Pada bagian pembahasan, diuraikan hasil kajian/penelitian dan hubungannya dengan kerangka teori atau kajian empirik terdahulu. Pada bagian ini dapat mnyertakan tabel dan gambar secara ringkas. Contoh penyajian tabel dan gambar sebagai berikut.

Pada siklus I pembelajaran dilaksanakan selama satu pertemuan, setiap pertemuan diadakan pre test dan post test. Untuk mengetahui perkembangan peserta didik selama pembelajaran. Siklus I membahas materi tentang selisih dua bilangan cacah dalam soal cerita.. Pembelajaran dengan model PBL dilaksanakan dengan 5 langkah PBL secara berurutan mulai dari Orientasi peserta didik pada masalah, mengorganisasikan peserta didik untuk belajar, membimbing penyelidikan individu maupun kelompok, mengembangkan dan menyajikan hasil karya; dan menganalisis dan mengevaluasi proses pemecahan masalah. Siswa dapat memecahkan masalah 
dari soal cerita. Berikut ini adalah hasil belajar peserta didik pada siklus I yang bisa dilihat pada tabel berikut.

Tabel 1. Prestasi Belajar Siklus I

\begin{tabular}{lccc}
\hline NILAI & JUMLAH SISWA & PROSENTASE \\
\hline Belum tuntas & $<70$ & 8 & $47 \%$ \\
\hline Tuntas & $>70$ & 7 & $53 \%$ \\
\hline
\end{tabular}

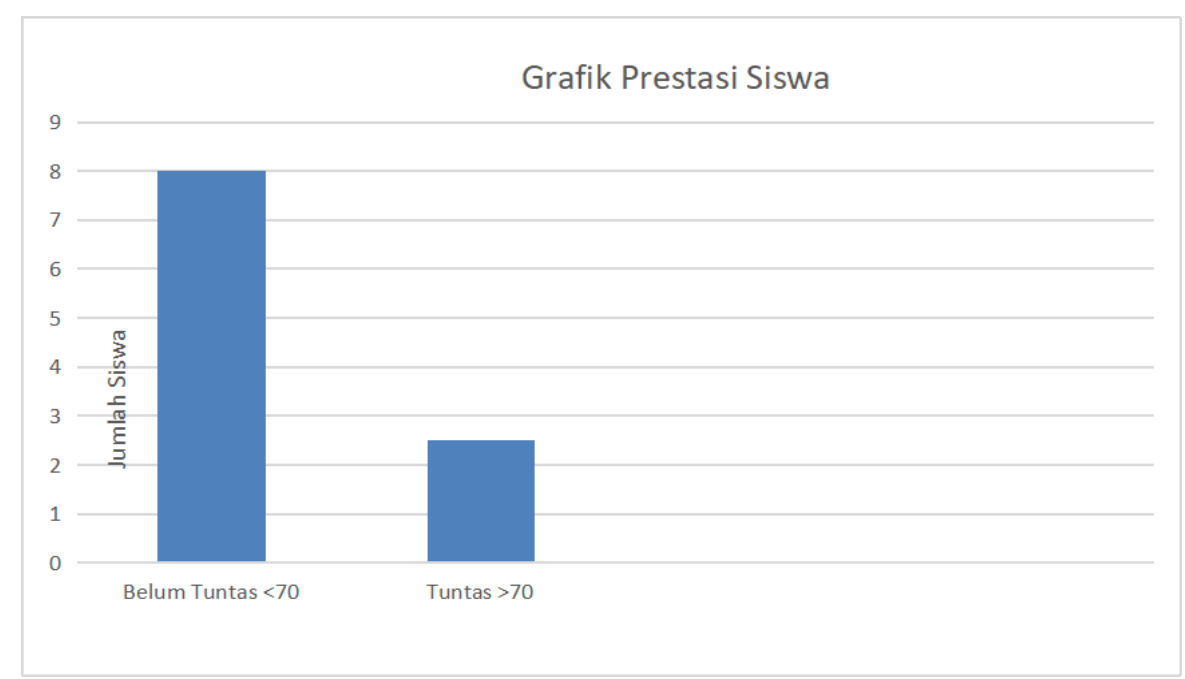

Gambar 1. Grafik Prestasi Siswa

Dari hasil pengamatan Peneliti ternyata Peningkatan Hasil Belajar Matematika Pada Materi Pengurangan Bilangan Dalam Bentuk Soal Cerita Melalui Problem Based Learning (PBL) Pada Siswa Kelas III SDN 1 Randurejo Kecamatan Pulokulon Kabupaten Grobogan Tahun Pelajaran 2020/2021" ini bisa dikatakan mempunyai pengaruh terhadap hasil belajar siswa. Dari 15 siswa terdapat 7 siswa tuntas dalam hasil belajarnya atau $47 \%$ dan 8 siswa belum tuntas hasil belajarnya atau $53 \%$ Akan tetapi perlu diperbaiki pada saat proses evaluasi. Pada tahap ini peneliti menilai bahwa peserta didik kurang diberikan waktu yang cukup dalam mengerjakan. Berdasarkan refleksi pada siklus I maka diputuskan untuk melanjutkan ke siklus II dikarenakan belum mencapai ketuntasan klasikal yang diharapkan. Siklus II membahas materi selisih dua bilangan cacah pada soal cerita. Pembelajaran dengan model PBL dilaksanakan dengan 5 langkah PBL secara berurutan seperti siklus I . Yaitu siswa menyelesaikan masalah yang disajikan. Berikut ini adalah hasil belajar peserta didik pada siklus II yang bisa dilihat pada tabel berikut.

Tabel 2. Prestasi Belajar Siklus I

\begin{tabular}{|c|c|c|c|}
\hline NILAI & & JUMLAH SISWA & PROSENTASE \\
\hline Belum tuntas & $<70$ & 12 & $80 \%$ \\
\hline Tuntas & $>70$ & 3 & $20 \%$ \\
\hline
\end{tabular}




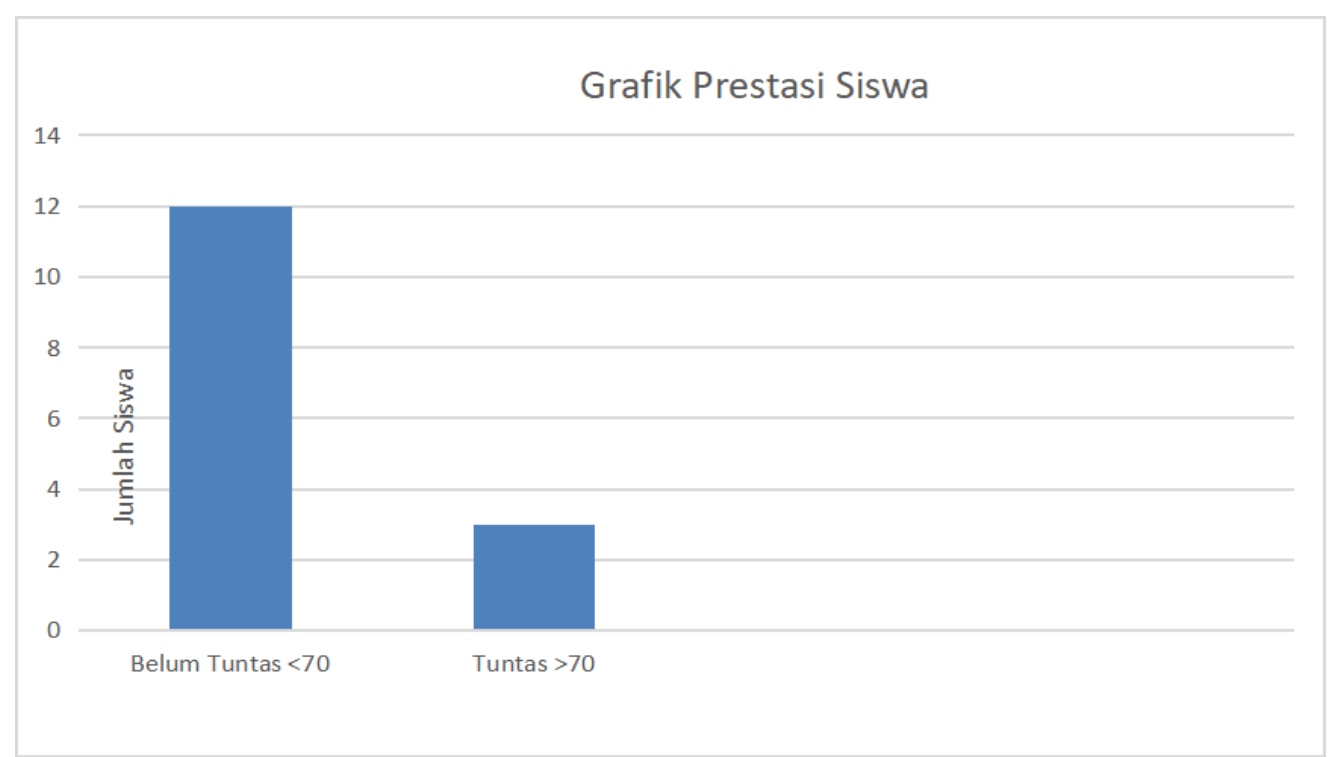

Gambar 2. Grafik Prestasi Siswa Siklus I

Ketuntasan klasikal mengalami peningkatan, pada siklus 2 terdapat 12 anak yang sudah tuntas dengan Kriteria Ketuntasan Minimal (KKM) sebesar 70. Persentase ketuntasan klasikalnya meningkat, jika pertemuan 1 hanya $47 \%$ maka pada pertemuan 2 menjadi $80 \%$.

Dari dua siklus yang sudah dilaksanakan selama 2 pertemuan dapat dipastikan bahwa model pembelajaran PBL dapat meningkatkan hasil belajar peserta didik pada

Mupel Matematika Kelas III di SD Negeri 1 Randurejo. Hal ini sesuai dengan konsep atau teori yang diungkap oleh Nanang Hanafiah dan Cucu Suhana (2009:30) bahwa langkah penerapan Model pembelajaran ini merupakan model pembelajaran inovatif yang melibatkan pemecahan masalah dimana peserta didik bekerja secara mandiri dalam mengkonstruksi pembelajarannya dan mengkulminasikannya dalam pemecahan masalah. Memang benar adanya dengan model PBL peserta didik akan membangun sendiri pengetahuannya dengan memecahkan masalah yang disajikan dalam soal cerita yang diberikan. Peserta didik dapat memahami komponen selisih dua bilangan cacah melalui soal cerita dengan tepat. Pada siklus II peserta didik sudah memahami konsep selisih dua bilangan cacah. Hasil penelitian ini juga sesuai dengan penelitian sebelumnya yaitu Penelitian dengan judul Penerapan Model Problem Based Learning Untuk Meningkatkan Keaktifan Dan Hasil Belajar Siswa Pada Pelajaran Komputer (Kk6) Di Smk N 2 Wonosari Yogyakarta menunjukkan bahwa pelaksanaan pembelajaran Model Based Learning sebagai model pembelajaran secara keseluruhan cukup efektif untuk meningkatkan hasil belajar siswa.

\section{SIMPULAN}

Penerapan model pembelajaran Problem Based Learning (PBL) dapat meningkatkan hasil belajar peserta didik Kelas III pada mupel Matematika materi selisih dua billangan cacah. Peningkatan yang terjadi karena adanya kesan pembelajaran yang mendalam dari peserta didik tehadap materi yang diajarkan melalui setiap pemecahan masalah yang disajikan dalam soal cerita. Peserta didik akan selalu teringat akan materi yang diajarkan dikarenakan mereka menemukan dan membangun sendiri pengetahuan mereka pada saat

menyelesaikan masalah yang disajikan. Berdasarkan penelitian yang telah dilaksanakan salah satu model pembelajaran yang harus dikuasai guru adalah PBL karena model ini sangat cocok digunakan dalam keadaan pandemi seperti ini, apalagi dalam kondisi belajar dari rumah. Peserta didik akan membangun pengetahuannya 
sendiri dengan pemecahan masalah yang membuat siswa berfikir kritis. Guru bisa memantau proses selama siswa menemukan jawaban dari permasalahan yang disajikan dan dilaksanakan dengan bekerja sama denagn orang tua.

\section{DAFTAR PUSTAKA}

Amir, T. (2015). Inovasi Pendidikan Melalui Problem Based Learning. Jakarta: Prenadamedia.

Arikunto, S., Suhardjono., dan Supardi. (2010). Penelitian Tindakan Kelas. Jakarta: Bumi Aksara

D. Setiawan, dkk. (2008). Komputer dan Media Pembelajaran. Jakarta: Universitas Terbuka.

M.S,Thayeb, (2006). Pendidikan Kewarganegaraan untuk SD Kelas II. Jakarta: Erlangga ( Hal. 55-58)

Muhsetyo, Gatot, dkk (2008). Pembelajaran Matematika SD. Jakarta: Universitas Terbuka

Rochiati Wiriaatmadja (2008). Metode Penelitian Tindakan Kelas untuk meningkatkan kinerja guru dan dosen. Bandung: Remaja Rosdakarya.

Tita Lestari (2009). Materi Pendampingan KTSP Supervisi Akademik Pembelajaran. Semarang: Unnes.

Wahyudini, D, Supriadi, Abdulhak, I. (2000). Pengantar Pendidikan. Jakarta: Universitas Terbuka.

Wibawa,B,Dr, (2003). Penelitian Tindakan Kelas. Jakarta: Departemen Pendidikan Nasional

Winataputra, U, dkk, (2004). Strategi Belajar Mengajar. Jakarta: Universitas Terbuka.

Winataputra, U, dkk, (2007). Teori Belajar dan Pembelajaran. Jakarta: Universitas Terbuka.

Winataputra, U, dkk, (2007). Materi dan Pembelajaran PPKn SD. Jakarta: Universitas Terbuka.

Zaenul, A\&Mulyana, A (2004). Tes dan Asessmen di SD. Jakarta: Universitas Terbuka. 